\title{
PENERAPAN RESTORATIF JUSTICE DALAM UNDANG-UNDANG SISTEM PERADILAN PIDANA ANAK
}

\author{
APPLICATION OF RESTORATIVE JUSTICE IN \\ CHILD CRIMINAL JUSTICE SYSTEM LAW
}

\author{
Arilasman Cornelius, Beniharmoni Harefa \\ Fakultas Hukum, Universitas Pembangunan Nasional Veteran Jakarta \\ Jalan RS. Fatmawati Nomor 1, Pondok Labu, Jakarta Selatan \\ Email: arilasman15@gmail.com
}

\begin{abstract}
Abstrak
Keberhasilan konsep restorative justice membutuhkan usaha yang kooperatif dari para penegak hukum agar tercipta sebuah alternatif untuk korban dan pelaku menyelesaikan konflik hukum mereka. Adanya restorative justice diharapkan mampu memberikan kepentingankepentingan para pihak dan para penegak hukum. Konsep Restorative justice menekankan hak asasi manusia serta memperhatikan keadilan serta efek negatif dalam pemberian sanksi pada keadilan formal atau hukum. Dari latar belakang permasalahan yang diambil dalam penelitian ini, maka akan dirumuskan identifikasi masalah yaitu penetapan diversi oleh Penuntut Umum terhadap anak yang sedang berkonflik dengan hukum di Kejaksaan Negeri Jakarta Barat dalam Sistem Peradilan Anak dan faktor-faktor yang menjadi kendala atau hambatan bagi Penuntut Umum dalam penyelesaian perkara pidana yang dilakukan oleh anak yang berhadapan dengan hukum dalam menerapkan Diversi. Jenis penelitian Penerapan Restoratif Justice Dalam UUPA (Undang-Undang Sistem Peradilan Pidana Anak) adalah bentuk jenis penelitian hukum normatif, yaitu dengan penelitian yang mengacu kepada peraturan perundang-undangan yang telah ada. Penelitian ini juga termasuk dalam penelitian kepustakaan. Dalam melakukan penelitian ini bahan hukum yang digunakan oleh peneliti adalah pengumpulan dari sebuah studi kepustakaan. Jaksa Penuntut Umum Kejaksaan Negeri Jakarta Barat menerapkan diversi pada sistem peradilan pidana yang dilakukan oleh anak dengan melakukan pendekatan kepada pelaku dan korban serta pihak-pihak yang terkait. Proses diversi yang dilakukan oleh Jaksa Penuntut Umum telah tercapai kesepakatan dengan pelaku serta orang tua pelaku meminta maaf kepada korban agar tindak pidana yang dilakukan oleh pelaku tidak diselesaikan melalui proses peradilan pidana. Selain itu juga terdapat beberapa hambatan bagi Penuntut Umum dalam penyelesaian perkara pidana anak dengan menerapkan Diversi.
\end{abstract}

Kata Kunci : Penerapan diversi, Hambatan, Sistem peradilan pidana anak.

\section{Abstract}

The success of the concept of restorative justice requires cooperative efforts from law enforcers to create an alternative for victims and perpetrators to resolve their legal conflicts. 
The existence of restorative justice is expected to be able to provide the interests of the parties and law enforcers. The concept of Restorative justice emphasizes human rights and pays attention to justice and the negative effects of sanctions on formal or legal justice. From the background of the problems taken in this study, the identification of problems will be formulated, namely the determination of diversion by the Public Prosecutor of children who are in conflict with the law at the West Jakarta District Prosecutor's Office in the Juvenile Justice System and the factors that become obstacles or obstacles to the Public Prosecutor in settlement of criminal cases committed by children who are in conflict with the law in implementing Diversion. The type of research on the Application of Restorative Justice in the UUPA (Law on the Criminal Justice System for Children) is a form of normative legal research, namely research that refers to the existing laws and regulations. This research is also included in library research. In conducting this research, the legal materials used by researchers were collection from a literature study. The West Jakarta Public Prosecutor's Office applies diversion to the criminal justice system committed by children by approaching the perpetrator and victim as well as related parties. The diversion process carried out by the public prosecutor has reached an agreement with the perpetrator and the perpetrator's parents apologized to the victim so that the criminal act committed by the perpetrator is not resolved through the criminal justice process. In addition, there are also several obstacles for the Public Prosecutor in solving juvenile criminal cases by implementing Diversion.

Keywords : Diversion application, Obstacles, Juvenile criminal justice system.

\section{A. Pendahuluan}

Anak melakukan perbuatan yang melanggar hukum dapat disebabkan karena berbagai faktor diantaranya adalah faktor dari adanya perkembangan globalisasi di bidang informasi komunikasi, perkembangan ilmu pengetahuan berbasis teknologi, perubahan gaya serta kehidupan masyarakat yang telah mengalami perubahan sosial akan sangat memberikan mempengeruhi perilaku anak.

Anak yang melakukan tindakan kriminal pada umumnya terpengaruh oleh perilaku negatif yang dilakukan oleh orang dewasa disekitarnya, namun bisa juga karena kurangnya kesadaran dan pengetahuan hukum yang menjadi faktor penentu anak melakukan tindak pidana. Kemajuan teknologi juga sangat berpotensi menimbulkan anak untuk melakukan suatu tindak pidana. $^{1}$ Anak melakukan tindak pidana banyak yang disebabkan oleh ketidaksadaran anak

\footnotetext{
${ }^{1}$ Pradityo, Randy. (2016). Garis Lurus Diversi Sebagai Pendekatan Non-Penal. Jurnal RechtsVinding Online. hlm 29. doi:10.25216/JHP.5.3.2016.319-330.
} 
tersebut bahwa perbuatan yang sedang dilakukan merupakan perbuatan yang melanggar hukum. Oleh sebab itu, anak yang telah dinyatakan melakukan suatu tindak pidana harus disikapi dengan bijaksana oleh sistem hukum peradilan. Apabila peradilan formal menempatkan anak yang melanggar hukum dengan sebutan narapidana akan menimbulkan efek negatif dalam perkembangan tumbuh kembang anak. ${ }^{2}$

Pemberian hukuman kepada anak dengan menerapkan sistem peradilan pidana formal seperti memasukkan anak ke dalam penjara tentu tidak akan memberikan efek jera kepada anak dan mengubah kepribadiannya menjadi lebih baik dari sebelumnya. Hukuman penjara justru berpotensi menjadikan anak menjadi penjahat yang profesional. ${ }^{3}$ Apabila seorang anak melakukan suatu perbuatan tindak pidana seperti tindak pidana yang dilakukan oleh orang-orang dewasa, maka anak tersebut harus diperlakukan layaknya seorang anak dan tetap harus mendapatkan perlindungan karena keadaan psikis dan fisik seorang anak dapat dikatakan belum sempurna. Inilah alasan anak yang melakukan suatu tindak pidana harus mendapatkan penanganan dan proses hukum yang berbeda dengan orang dewasa.

Terdapat pedoman dalam proses peradilan pidana anak dengan tujuan untuk menghindari dampak negatif dari sanksi pidana yang diberikan kepada anak. Upaya untuk menghindari dampak negatif dari sanksi pidana tersebut merupakan kewenangan dari aparat para penegak hukum yang salah satunya merupakan jaksa penuntut umum. ${ }^{4}$ Jaksa penuntut umum memiliki kewenangan untuk mengambil alternatif lain dalam proses penuntutan dengan melakukan tindakan-tindakan kebijakan menghentikan dengan tidak meneruskan perkara, mengembalikan anak kepada orang tuanya agar, atau menyerahkan anak kepada lembaga sosial lainnya. Hal inilah yang disebut dengan upaya diversi, dengan memberikan upaya diversi ini diharapkan

\footnotetext{
${ }^{2}$ Setiawan, Dian Alan.(2017). Efektivitas Penerapan Diversi Terhadap Penanganan Anak Yang Berhadapan Dengan Hukum Dalam Peradilan Pidana Anak Sesuai Undang-Undang Republik Indonesia Nomor 11 Tahun 2012 Tentang Sistem Peradilan Pidana Anak. DiH Jurnal Ilmu Hukum, Volume 13 Nomor 26. Fakultas Hukum Universitas 17 Agustus Surabaya. hlm. 73. doi: https://doi.org/10.30996/dih.v0i0.1585

3 Jonlar Purba. (2017). Penegakan Hukum Terhadap Tindak Pidana Bermotif Ringan Dengan Restorative Justice, Jakarta : Jala Permata Aksara. hlm. 29. doi: http://dx.doi.org/10.26532/ijlr.v3i1.4366

${ }^{4}$ Randy Pradityo. (2016). Restorative Justice Dalam Sistem Peradilan Pidana Anak Restorative Justice In Juvenile Justice System. Jurnal Hukum dan Peradilan, Volume 5 Nomor 3.hlm. 324. doi:10.25216/JHP.5.3.2016.319-330
} 
dapat mengurangi dampak negatif dari sanksi pidana agar anak tidak melakukan kejahatan yang lebih parah lagi setelah proses pengadilan. ${ }^{5}$

Kebijakan restorative justice dapat menjadi suatu alternatif untuk menangani kasus pidana yang dilakukan oleh anak. Adanya upaya restorative justice diharapkan dapat tercipta keadilan bagi seluruh pihak dan mencegah terjadinya kejahatan yang lain. Mekanisme dan tata cara peradilan pidana dengan kebijakan restorative justice berfokus pada proses pemidanaan dengan mediasi untuk mencapai suatu kesepekatan dalam penyelesaian perkara pidana anak yang adil dan seimbang untuk pihak korban maupun pihak pelaku. ${ }^{6}$ Restorative justice merupakan tindakan dengan tujuan sebagai pemulihan hubungan atau perbaikan hubungan antara pelaku dengan korban. Proses mediasi ini dengan penyempaian kerugian korban dan pemberian kesempatan pelaku untuk menebus kesalahannya dengan memberikan ganti rugi, sanksi pidana sosial, atau kesepakatan lainnya yang dapat mendamaikan kedua belah pihak. $^{7}$

Adanya UU No. 11 Tahun 2012 tentang Sistem Peradilan Pidana Anak (SPPA), menjadi sebuah pedoman peraturan untuk masyarakat dan para penegak hukum dalam memberikan perlindungan untuk anak, khususnya untuk anak yang sedang bermasalah dengan hukum. Dalam UU No. 11 Tahun 2012 tentang Sistem Peradilan Pidana Anak (SPPA) ini juga menerapkan upaya diversi dalam proses penyelesaian perkara pidana yang dilakukan oleh anak serta menetapkan kebijakan restorative justice agar dapat membantu proses pemulihan keadaaan antara pelaku dan korban menjadi lebih baik. Seperti studi kasus yang diambil peneliti dalam melakukan penelitian ini, yaitu studi kasus penetapan PN Jakarta Barat No. 39/Pen.Diversi/Pid.Sus-Anak/2019/PN.Jkt.Brt. ${ }^{8}$ Dalam kasus ini bermula dari komentar anak di sosmed perihal larangan agar tidak membuli temannya Sean Calvin yang sekolah di SMA Tarakanita, kemudian saksi Richard Chandra membalas komentar anak dan menantang anak, kemudian pada bulan November 2018 anak mendatangi Richard Chandra di sekolahnya

\footnotetext{
${ }^{5}$ Waluyo, Bambang. (2016). Desain Fungsi Kejaksaan Pada Restorative Justice. Jakarta: Rajawali Pers. hlm. 62.

${ }^{6}$ Kirom, Mizanul., Pujiyono, Endah Sri. (2016). Implementasi Diversi Dalam Penyelesaian Kasus Anak Yang Berkonflik Dengan Hukum Berdasarkan Undang-Undang Nomor 11 Tahun 2012 Tentang Sistem Peradilan Pidana Anak. Diponegoro Law Jurnal, Volume 5 Nomor 3. hlm. 12.

${ }^{7}$ Wiyono, R. (2016). Sistem Peradilan Pidana Anak Di Indonesia. Jakarta: Sinar Grafika.

${ }^{8}$ Penetapan Pengadilan Negeri Jakarta Barat Nomor 39/Pen.Diversi/Pid.Sus-Anak/2019/PN.Jkt.Brt
} 
Tarakanita lalu temandari saksi Richard Chandra menantang anak dan anak menerima tantangan dari teman saksi Richard Chandra tersebut. Sekitar seminggu kemudian pada tanggal 27 November 2018 teman dari saksi Richard Chandra yang bernama Calvin Andreano menantang anak dan mengajak anak bertemu dengan mengatakan kepada anak untuk membawa serta temantemannya ke pom bensin shell Latumenten. Sampai di pom bensin Latumenten anak bertemu dengan saksi Steve Jordan yang mengatakan kepada anak bahwa dirinya juga ada masalah dengan teman dari saksi Richard Chandra. Tidak lama kemudian saksi Richard Chandra datang bersama teman temannya sehingga terjadi keributan selanjutnya anak melempar gembok dan mengenai gigi Richard Chandra sehingga giginya patah.

Korban Richard Chandra menerangkan bahwa dirinya dilempar menggunakan gembok oleh seseorang yang setelahnya korban ketahui bernama Andrew Vinz. Korban menerangkan bahwa dirinya berusia 15 tahun, maka didapatkan kesimpulan bahwa pada saat terjadi peristiwa penganiayaan tersebut anak korban menurut undang-undang dikategorikan sebagai anak. Dalam kasus ini, anak dianggap masih labil sehingga mudah terpengaruh dengan lingkungan sekitarnya. Anak menyesali perbuatannya dan tidak akan mengulangi perbuatannya. Pihak orang tua anak juga berjanji bahwa akan meningkatkan pengawasan dan perhatian lebih terhadap anak. Sehingga memberikan rekomendasi untuk dilakukan upaya Diversi terhadap anak dan mengembalikan anak kepada orang tua dibawah bimbingan BAPAS atau Balai Pemasyarakatan.

Apabila ditinjau dari teori-teori pemidanaan, adanya sanksi pidana untuk pelaku tindak pidana memiliki tiga tujuan yang ingin dicapai diantaranya adalah untuk menegakkan tata tertib dalam hukum, untuk mencegah terjadinya tindak kejahatan, serta untuk memberikan efek jera dan tidak melakukan kejahatan lagi ${ }^{9}$. Sanksi pidana pada umumnya harus bersifat membuat pelaku jera, memperbaiki, dan mendidik pelaku tindak pidana untuk tidak melakukan tindakannya lagi. Adanya pemberian sanksi pidana adalah bentuk implementasi dari penerapan sanksi pidana untuk pelaku yang ditujukan untuk keamanan dan perlindungan masyarakat. ${ }^{10}$

\footnotetext{
${ }^{9}$ Karim. (2016). Tanggung Jawab Pelaku Pidana Pelanggaran Dalam Perspektif Restorative Justice. Jurnal Ilmu Hukum, Universitas Airlangga, Volume 31 Nomor 3. doi: https://doi.org/10.21107/ri.v12i2.3244

${ }^{10}$ Hasbi Hasan. (2013). Penerapan Keadilan Restoratif Dalam Sistem Peradilan Pidana Anak Di Indonesia. Jurnal Hukum dan Peradilan. Volume 2 Nomor 2. hlm. 249. doi: http://dx.doi.org/10.25216/jhp.2.2.2013.247-262
} 
Namun, konsep restorative justice belum sepenuhnya dapat dilakukan secara komprehensif oleh masyarakat dan penegak hukum. Implementasi dari konsep restorative justice dalam prakteknya masih diselimuti berbagai perdebatan. ${ }^{11}$ Banyak masyarakat yang memahami bahwa konsep restorative justice sama dengan mediasi, hal ini membuat konsep restorative justice dipahami sebagai suatu usaha perdamaian yang dilakukan di luar pengadilan. Padahal konsep restorative justice dengan mediasi sangat berbeda. Banyak juga masyarakat yang khawatir adanya konsep restorative justice akan merusak tujuan keadilan karena menganggap tidak mampu memberikan efek jera kepada pelaku yang melakukan tindak pidana. ${ }^{12}$

Keberhasilan konsep restorative justice membutuhkan usaha yang kooperatif dari para penegak hukum agar tercipta sebuah alternatif untuk korban dan pelaku menyelesaikan konflik hukum mereka. ${ }^{13}$ Adanya restorative justice diharapkan mampu memberikan kepentingankepentingan para pihak dan para penegak hukum. Kebijakan restorative justice menekankan kepada hak asasi manusia dan memperhatikan keadilan serta dampak dalam pemberian sanksi pada keadilan formal atau hukum. ${ }^{14}$ Berdasarkan latar belakang masalah tersebut ${ }^{15}$, maka akan dirumuskan identifikasi masalah yaitu penetapan diversi yang dilakukan oleh Penuntut Umum terhadap anak yang berhadapan dengan hukum di Kejaksaan Negeri Jakarta Barat dalam Sistem Peradilan Pidana Anak (SPAA) dan faktor yang menjadi hambatan bagi Penuntut Umum dalam penyelesaian perkara anak yang berhadapan dengan hukum dengan menerapkan Diversi.

\section{B. METODE PENELITIAN}

Dalam melakukan penelitian ini peneliti menggunakan metode penelitian hukum normatif dimana peneliti melakukan pengkajian tentang peraturan perundang-undnagan, teoriteori hukum, dan putusan yang berhubungan dengan permasalahan penerapan restorative justice.

\footnotetext{
11 Mita Dwijayanti. (2017). Diversi Terhadap Recidive Anak. Jurnal Rechtidee, Volume 12 Nomor 2 . hlm. 232. doi: https://doi.org/10.21107/ri.v12i2.3244

12 Isnatul Rahmi, Rizanizarli. (2020). Penerapan Restorative Justice Dalam Penyelesaian Tindak Pidana Pencurian Oleh Anak Dalam Perspektive Adat Aceh (Suatu Penelitian di Wilayah Kota Sabang). Jurnal Syiah Kuala Law Journal, Volume 4 Nomor 1. hlm. 13. doi: https://doi.org/10.24815/sklj.v4i1.16876

${ }^{13}$ Hatta. (2016). Kapita Selekta Pembaharuan Hukum Pidana dan Sistem Pemidanaan. Yogayakarta: Liberti. hlm. 82 ${ }^{14}$ Husin, Kadri, Budi Rizki. (2016). Sistem Peradilan Pidana di Indonesia. Jakarta: Sinar Grafika. hlm. 28.

15 Marzuki, Peter Mahmud. (2016). Penelitian Hukum (Suatu Pengantar). Jakarta: Kencana Prenada Media. hlm. 29.
} 
Selain itu peneliti juga melakukan penelitian di di Kejaksaan Negeri Jakarta Barat untuk mengetahui penetapan upaya diversi yang dilakukan oleh Penuntut Umum terhadap anak yang bermasalah dengan hukum dalam (SPAA) atau Sistem Peradilan Pidana Anak. Penelitian ini juga dapat dikatakan sebagai penelitian kepustakaan. Bahan-bahan hukum dalam penelitian ini menggunakan proses pengumpulan dari sebuah studi kepustakaan. Proses pengumpulan bahanbahan hukum yang digunakan dalam penelitian ini adalah telaah pustaka dengan cara melakukan penelusuran terhadap norma-norma yang mengatur tentang penerapan restoratif justice dalam peradilan pidana anak. Penelitian ini menitikberatkan pada bahan pustaka yang bersumber dari penelitian hukum sosiologis atau empiris yang diteliti. ${ }^{16}$

Dalam penelitian hukum normatif ini sumber data yang digunakan adalah data-data yang yang terdiri dari bahan hukum primer, sekunder, serta bahan hukum tersier. Bahan Hukum Primer dalam penelitian ini adalah menggunakan peraturan perundang-undangan yang mengatur permasalahan dalam penelitian ini. Sedangkan bahan hukum sekunder dari penelitian ini meliputi data yang terkait mengenai Penetapan PN Jakarta Barat No. 39/Pen.Diversi/Pid.SusAnak/2019/PN.Jkt.Brt, yang peneliti dapatkan dari instansi yang terkait yaitu PN Jakarta Barat sebagai lokasi penelitian dilakukan. Serta bahan hukum tersier adalah bersumber dari pendapat hukum atau istilah-istilah hukum yang diperoleh dari buku, hasil penelitian, jurnal hukum, kamus hukum, dan makalah-makalah hukum.

Teknik pengumpulan data penelitian ini dengan mengumpulkan metode studi literatur, hal ini dilakukan agar mendapatkan bahan-bahan hukum yang sesuai dengan jenis penelitian yang digunakan. Dalam pengumpulan data ini peneliti terlebih dahulu mengklasifikasikan bahanbahan hukum pada pokok masalah yang akan dibahas, yaitu bahan-bahan hukum mengenai hukum pidana anak, dan putusan yang menjadi bahan dengan penelitian ini. Bahan-bahan hukum yang telah terkumpul, kemudian dilakukan pengolahan data dengan mengkaji secara mendalam sehingga peneliti akan memperoleh gambaran mengenai permasalah hukum yang akan diteliti.

\footnotetext{
${ }^{16}$ Pradityo, Randy. (2016). Restorative Justice Dalam Sistem Peradilan Pidana Anak Restorative Justice In Juvenile Justice System. Jurnal Hukum dan Peradilan, Volume 5 Nomor $3 . \quad$ Hlm. 324. doi: http://dx.doi.org/10.25216/jhp.5.3.2016.319-330
} 
Data yang telah terkumpul kemudian dianalisis secara mendalam agar dapat menjawab beberapa permasalahan yang diambil dalam penelitian. Proses analisis menggunakan sebuah deskriptif analisis dengan mengemukaan kasus dalam sebuah putusan yang menjadi objek dalam penelitian ini agar jelas keadaan dan kondisinya. Analisis ini merupakan salah satu upaya untuk mendapatkan solusi dari masalah yang ditemukan, dan menetapkan hubungan antar permasalahan yang telah ditemukan agar mengetahui cara penyelesaiannya. Untuk menjawab fokus permasalahan yang terdapat dalam judul, peneliti kemudian melakukan pengumpulan bahan hukum melalui studi kepustakaan dengan menganalisis terhadap sejumlah peraturan perundang-undangan, dokumen hukum, jurnal-jurnal hukum, hasil-hasil karya ilmiah, serta bahan bacaan/literatur yang berasal dari ilmu pengetahuan hukum yang ada kaitannya dengan penelitian ini. ${ }^{17}$

\section{PEMBAHASAN}

\section{PENETAPAN UPAYA DIVERSI YANG DILAKUKAN OLEH PENUNTUT UMUM TERHADAP ANAK YANG BERMASALAH DENGAN HUKUM DI KEJAKSAAN NEGERI JAKARTA BARAT DALAM SPPA}

Upaya penyelesaian permasalahan hukum pidana yang dilakukan oleh anak dengan menggunakan upaya diversi dilakukan sebagai upaya untuk menghindari efek negatif yang akan berdampak pada jiwa dan perkembangan anak yang sedang bermasalah dengan hukum. Pelaksanaan diversi ini dilakukan oleh aparat penegak hukum. Dengan menerapkan upaya diversi dalam proses penyelesaian peradilan pidana anak akan memberikan perlindungan hukum untuk anak dari sanksi pidana penjara. ${ }^{18}$ Diversi dilakukan sebagai upaya rehabilitasi kepada pelaku agar pelaku yang dalam hal ini adalah anak-anak tidak menjadi pelaku kejahatan kriminal dewasa. Dalam UU No. 11 Tahun 2012 Tentang Sistem Peradilan Pidana Anak dijelaskan bahwa pada kebijakan restoratif justice merupakan suatu proses diversi. Hal ini berarti para pihak yang

\footnotetext{
${ }^{17}$ Moleong, Lexy J. (2017). Metodelogi Penelitian Kualitatif . Bandung: PT Remaja Rosda Karya.

18 Azizah, Hikmatul, Abd Wahid, Arfan Kaimuddin. (2021). Implementasi Penyelesaian Perkara Melalui Diversi Berdasarkan UU No.11 Tahun 2012 Tentang Sistem Peradilan Pidana Anak (Studi Kasus di Kejaksaan Negeri Kota Malang), Jurnal Dinamika, Volume 27 Nomor 3. hlm. 457
} 
terlibat dalam suatu perbuatan tindak pidana, diusahakan secara bersama-sama untuk mengatasi masalah agar tercipta keadaan yang lebih baik untuk pelaku, korban, dan masyarakat. Diversi juga dapat dijadikan solusi untuk memperbaiki hubungan dan memberikan ketentraman kepada semua pihak karena sanski yang diberikan tidak berlandaskan pembalasan. ${ }^{19}$

Dalam proses diversi sistem peradilan pidana anak, melibatkan seluruh komponen dari setiap aparatur penegak hukum mulai dari tingkat di kepolisian, di kejaksaan, hingga di pengadilan. Dalam proses pelaksaan diversi para penegak hukum harus memiliki tujuan yang sama yaitu sesuai dengan Pasal dalam UU No. 11 Tahun 2012 tentang Sistem Peradilan Pidana Anak yang menyatakan bahwa semua komponen penegak hukum harus menjadi satu kesatuan dalam wadah dalam sistem peradilan pidana, serta ketiga komponen penegak hukum ini harus mampu berjalan secara bersinergi agar terbangun sistem hukum yang mampu memberikan perlindungan hukum dan rasa keadilan khususnya terhadap anak yang sedang berkonflik dengan hukum. ${ }^{20}$

Dalam penerapan konsep upaya diversi pada proses peradilan formal yang telah ada, perlindungan bagi anak dari tindakan pemenjaraaan akan semakin diutamakan. Selain itu perlindungan anak dengan menerapkan upaya diversi dengan melakukan pada semua tingkatan peradilan mulai dari lingkungan masyarakat dengan tujuan untuk melakukan pencegahan agar tidak terjadi suatu perbuatan tindak pidana. Dalam hal ini apabila menemukan anak telah melakukan suatu pelanggaran hukum masyarakat tidak perlu langsung melakukan pelaporan ke polisi untuk diproses dengan hukum. ${ }^{21}$ Namun, apabila anak yang sudah melakukan pelanggaran

\footnotetext{
19 Mahendra, Alfian dan Beniharmoni Harefa. (2020). Perlindungan Hukum Terhadap Identitas Anak Sebagai Pelaku Tindak Pidana Dalam Proses Peradilan Pidana. Jurnal Kertha Semaya, Volume 8 Nomor 10. hlm. 1630. doi: https://doi.org/10.24843/KS.2020.v08.i10.p13

20 Setiawan, Dian Alan. (2017). Efektivitas Penerapan Diversi Terhadap Penanganan Anak Yang Berhadapan Dengan Hukum Dalam Peradilan Pidana Anak Sesuai Undang-Undang Republik Indonesia Nomor 11 Tahun 2012 Tentang Sistem Peradilan Pidana Anak. DiH Jurnal Ilmu Hukum, Volume 13 Nomor 26. hlm. 235. doi: https://doi.org/10.30996/dih.v0i0.1585

${ }^{21}$ Ariani, Ni Made Ita, Ni Putu Rai Yuliartini, Dewa Gede Sudika Mangku. (2019). Implementasi Undang-Undang Nomor 11 Tahun 2012 Tentang Sistem Peradilan Pidana Anak Terhadap Curanmor Yang Dilakukan Oleh Anak Di Kabupaten Buleleng (Studi Kasus Perkara Nomor : B/346/2016/RESKRIM). e-Journal Komunitas Yustisia Universitas Pendidikan Ganesha Jurusan Ilmu Hukum, Volume 2 Nomor 2, hlm. 107. doi: http://dx.doi.org/10.23887/jatayu.v2i2.28776
} 
hukum tersebut telah terlanjur ditangkap oleh pihak kepolisian, maka dalam proses pemeriksaan peradilannya kepolisian dapat menerapkan konsep diversi dengan menghentikan pemeriksaan yang tujuannya demi perlindungan terhadap pelaku anak. Namun, apabila kasus anak yang melanggar hukum ini sudah sampai ke ranah pengadilan, maka dalam hal ini hakim harus dapat mengimplementasikan diversi sesuai dengan prosedur dan mengutamakan kepentingan anak agar dapat dibebaskan dari sanksi pemidanaan penjara. Proses penahanan anak dalam penjara yang dilakukan terhadap anak yang berkonflik dengan hukum harus tetap memperhatikan pedoman yang ada pada aturan hukum terkait hak-hak anak yang telah tercantum pada konvensi hak anak. $^{22}$

Pada proses penyelesaian peradilan pidana anak, struktur proses penyelesaian perkara pidana dalam penyidikan dilakukan oleh jaksa penuntut umum. Jaksa penuntut umum adalah salah satu dari aparat penegak hukum yang memiliki wewenang untuk melaksanakan diversi. ${ }^{23}$ Hal ini telah diatur dalam Pasal 7 ayat 1 UU No. 12 Tahun 2012 tentang Sistem Peradilan Pidana Anak yang menyatakan bahwa mulai dari tingkat penyidikan, kemudian penuntutan, sampai ke pemeriksaan perkara pidana anak di tingkat pengadilan wajib mengupayakan diversi. Pengaturan terkait dengan tata cara pelaksanaan diversi telah diatur dalam Pasal 41 UU No 11 Tahun 2012 tentang Sistem Peradilan Pidana Anak diantaranya adalah sebagai berikut ${ }^{24}$ :

a) Jaksa penuntut umum diwajibkan melakukan upaya diversi dengan jangka waktu paling lama adalah 7 hari setelah diterimanya berkas perkara dari pihak penyidik

b) Upaya diversi yang dilakukan oleh jaksa penuntut umum dilakukan paling lama 30 (tiga puluh) hari

c) Apabila upaya diversi telah mendapatkan kesepakatan, jaksa penuntut umum harus menyampaikan dan menuliskannya pada berita acara beserta kesepakatan diversi

22 Andriyanti, Eka Fitri. (2020). Urgensitas Implementasi Restorative Justice Dalam Hukum Pidana Indonesia. Jurnal Education and development Institut Pendidikan Tapanuli Selatan, Volume 8 Nomor 4. hlm. 328. doi: https://doi.org/10.52103/jlg.v2i1.287

23 Widodo. (2017). Perspektif Hukum Pidana dan Kebijakan Pemidanaan: Diversi dan Keadilan Restoratif, Terorisme, Cybercrime, Pidana Mati, dan Peradilan Sesat. Yogyakarta: Aswaja Pressindo. hlm. 71.

${ }^{24}$ Undang-Undang No 11 Tahun 2012 tentang Sistem Peradilan Pidana Anak 
kemudian diserahkan kepada pengadilan negeri agar kemudian dibuatkan surat ketatapan

d) Apabila upaya diversi yang telah diupayakan ternyata tidak tercapai kesepakatan, maka jaksa penuntut umum wajib harus menyampaikan dan menuliskannya berita acara diversi dan kemudian melimpahkan perkara anak tersebut kepada pengadilan negeri dengan melampirkan laporan hasil penelitian kemasyarakatan ke pengadilan.

Pelaksanaan proses diversi dilakukan di dalam Ruangan Khusus untuk Anak (RKA). Dalam proses diversi ini jaksa penuntut umum bertindak sebagai fasilitator yang berwenang memulai proses diversi dengan memperkenalkan semua pihak, dan menjelaskan maksud serta tujuan dilakukannya upaya diversi, tata tertib selama proses diversi berlangsung, serta kronologi tindak pidana yang sedang didakwakan. ${ }^{25}$ Seluruh pihak yang terkait dalam pelaksanaan diversi kemudian diberikan kesempatan oleh jaksa penuntut umum selaku fasilitator untuk memberikan pendapat, tanggapan, serta saran mengenai tindak pidana tersebut. Setelah proses diversi dilaksanakan maka ditulislah berita acara diversi dan kemudian ditandatangani oleh fasilitator dan semua pihak yang terlibat. Berita acara diversi tersebut kemudian dilaporkan kepada Kepala Kejaksaan Negeri. Namun apabila, upaya diversi yang dilakukan tidak mendapatkan kesepakatan perdamaian maka JPU melimpahkan berkas perkara ke Pengadilan Negeri. ${ }^{26}$

Penerapan pelaksanaan diversi oleh JPU, seperti studi kasus yang diambil peneliti dalam melakukan penelitian ini, yaitu studi kasus penetapan PN Jakarta Barat No. 39/Pen.Diversi/Pid.Sus-Anak/2019/PN.Jkt.Brt. ${ }^{27}$ Kasus ini bermula dari komentar anak di sosmed perihal larangan agar tidak membuli temannya Sean Calvin yang sekolah di SMA Tarakanita, kemudian saksi Richard Chandra membalas komentar anak dan menantang anak, kemudian pada bulan November 2018 anak mendatangi Richard Chandra di sekolahnya

${ }^{25}$ Paksi, T. F. (2016). Merefleksi Pendekatan Sosio- Legal Dalam Penelitian Hukum" dalam Penelitian Hukum Interdisipliner. Yogyakarta : Thafa Media.

${ }^{26}$ Marlina, Renhard Harve., Muhammad Ekaputra, Edy Ikhsan. (2016). Penerapan Diversi Pada Tingkat Penuntut Umum Terhadap Anak Sebagai Pelaku Tindak Pidana Menurut UU Nomor 11 Tahun 2012 (Studi Kasus Di Cabang Kejaksaan Negeri Padangsidimpuan Di Sibuhuan). USU Law Journal, Volume 4 Nomor 3. hlm. 203.

${ }^{27}$ Penetapan Pengadilan Negeri Jakarta Barat Nomor 39/Pen.Diversi/Pid.Sus-Anak/2019/PN.Jkt.Brt 
Tarakanita lalu temandari saksi Richard Chandra menantang anak dan anak menerima tantangan dari teman saksi Richard Chandra tersebut. Sekitar seminggu kemudian pada tanggal 27 November 2018 teman dari saksi Richard Chandra yang bernama Calvin Andreano menantang anak dan mengajak anak bertemu dengan mengatakan kepada Richard untuk membawa serta teman-temannya ke pom bensin shell Latumenten. Sampai di pom bensin Latumenten anak bertemu dengan saksi Steve Jordan yang mengatakan kepada anak bahwa dirinya juga ada masalah dengan teman dari saksi Richard Chandra. Tidak lama kemudian saksi Richard Chandra datang bersama teman temannya sehingga terjadi keributan selanjutnya anak melempar gembok dan mengenai gigi Richard Chandra sehingga giginya patah.

Korban Richard Chandra menerangkan bahwa dirinya dilempar menggunakan gembok oleh seseorang yang setelahnya korban ketahui bernama Andrew Vinz. Korban menerangkan bahwa dirinya berusia 15 tahun, maka didapatkan kesimpulan bahwa pada saat terjadi peristiwa penganiayaan tersebut anak korban menurut undang-undang dikategorikan sebagai anak. Dalam kasus ini, anak dianggap masih labil sehingga mudah terpengaruh dengan lingkungan sekitarnya. Anak menyesali perbuatannya dan tidak akan mengulangi perbuatannya. Pihak orang tua anak juga berjanji bahwa akan meningkatkan pengawasan dan perhatian lebih terhadap anak. Sehingga memberikan rekomendasi untuk dilakukan upaya Diversi terhadap anak dan mengembalikan anak kepada orang tua dibawah bimbingan BAPAS.

Penerapan diversi ini memberikan kesempatan kepada pembimbing kemasyarakatan, pelaku, korban, para orang tua pelaku dan korban, pendamping, penasehat hukum, perwakilan masyarakat, untuk menyampaikan pendapat, tanggapan, dan saran dalam proses berlangsungnya proses diversi tersebut. Jaksa Penuntut Umum dalam proses pengambilan keputusan berlandasakan pada kebaikan pelaku dan korban. Dalam perkara ini Jaksa Penuntut Umum Kejaksaan Negeri Jakarta Barat menerapkan diversi pada sistem peradilan pidana anak dengan melakukan pendekatan kepada pelaku dan orang tua pelaku, korban, dan para orang tua pelaku dan korban, Balai Pemasyarakatan, serta masyarakat sekitar pelaku dan korban. Proses diversi yang dilakukan oleh Jaksa Penuntut Umum telah tercapai kesepakatan dengan pelaku dan orang tua pelaku kemudian meminta maaf kepada korban atas pebuatan yang telah dilakukan pelaku 
agar perbuatan pelaku yang termasuk dalam tindak pidana tersebut tidak dilanjutkan dalam proses peradilan pidana. Kemudian untuk mendapatkan kekuatan hukum bahwa diversi yang dilakukan telah tercapai kesepakatan diantara para pihak, maka berita acara upaya diversi dan hasil penelitian Badan Pemasyarakatan akan dialihkan ke PN Jakarta Barat untuk selanjutnya dilakukan penetapan oleh Ketua PN Jakarta Barat.

Pelaksanaan konsep diversi sangat bermanfaat terhadap setiap proses perlindungan anak yang sedang bermasalah dengan hukum. Hal ini merupakan prinsip utama adanya upaya diversi yaitu agar perbuatan tindak pidana yang dilakukan oleh anak terhindar dari proses penyelesaian perkara peradilan pidana formal dan memberikan dukungan serta kesempatan kepada pelaku anak untuk menjalankan sanksi lain sebagai alternatif tanpa perlu adanya sanksi pidana penjara. Penerapan konsep diversi merupakan mekanisme musyawarah untuk mencapai mufakat yang merupakan salah satu upaya untuk menerapkan hukum yang telah hidup berdampingan dengan masyarakat Dengan demikian, dalam keadilan restorative justice sebenarnya mengandung keinginan-keinginan para penegak hukum untuk melakukan pembelajaran moral, memberikan efek jera, partisipasi serta perhatian masyarakat terhadap hukum, pemulihan hubungan dengan saling memaafkan, serta memberikan rasa tanggungjawab terhadap hukum kepada seluruh masyarakat. $^{28}$

\section{FAKTOR YANG MENJADI PERMASALAHAN BAGI PENUNTUT UMUM DALAM PENYELESAIAN PERKARA ANAK YANG BERHADAPAN DENGAN HUKUM DENGAN MENERAPKAN DIVERSI}

Jaksa Penuntut Umum merupakan aparat penegak hukum yang memiliki wewenang melaksanakan upaya diversi. Dalam hal ini JPU juga memiliki beberapa permasalahan, hambatan serta kendala dalam pelaksanaan penerapan konsep diversi tersebut. Tahapan-tahapan upaya

\footnotetext{
${ }^{28}$ Sitanggang, Betania Fransiska, Irma Cahyaningtyas. (2020). Penanganan Perkara Anak Dalam Perspektif Jaksa Penuntut Umum. Jurnal Pembangunan Hukum Indonesia Program Studi Magister Ilmu Hukum, Volume 2 Nomor 1. hlm. 68.
} 
diversi tidak dapat berjalan maksimal apabila dalam penyelesaian perkara tindak pidana yang dilakukan oleh anak terdapat ketidaksepahaman visi atau tujuan dari sistem kebijakan restorative justice. ${ }^{29}$ Yang menjadi hambatan dalam proses penerapan diversi sebagai upaya penyelesaian perkara pidana anak yang bermasalah dengan hukum terdapat faktor internal dan faktor eksternal. Hambatan yang menjadi faktor eksternal diantaranya adalah ${ }^{30}$ :

a) Banyaknya permasalahan anak yang berkonflik dengan hukum sehingga kebutuhan fasilitas kurang memadai

b) Terdapat perbedaan pemahaman antara pelaku dan korban

c) Kurangnya kerja sama diantara para pihak yang terlibat

d) Terhambatnya informasi dan data-data yang terkait diantara para penegak hukum

e) Kurangnya koordinasi diantara para penegak hukum

f) Tidak adanya persamaan pendapat diantara aparat penegak hukum dalam menangani kepentingan anak yang berkonflik dengan hukum

g) Kurangnya sarana dan prasarana dalam proses diversi

h) Masih Kurangnya kebijakan dalam proses rehabilitasi atau pemulihan sosial dalam mengangani anak nakal.

Selain itu hambatan yang menjadi faktor internal diantaranya adalah :

a) Kurangnya payung hukum yang menyebabkan kurangnya pemahaman semua pihak terhadap implementasi keadilan restoratif, meskipun tujuannya adalah pemulihan bagi pelaku, korban, masyarakat. Hal ini akan mempersulit para pihak melakukan upaya diversi.

b) Masih kurangnya peraturan hukum yang dijadikan landasan untuk pagi para penegak hukum mengenai permasalahan penerapan tindak pidana anak. Beragamnya permasalahan tentang batasan minimal umur seseorang dapat dikatakan "anak"

\footnotetext{
${ }^{29}$ Mulyadi, Lilik. (2016). Mediasi Penal Dalam Sistem Peradilan Pidana Indonesia. Bandung : PT Alumni. hlm. 11.

${ }^{30}$ Aidil., M. (2020). Penerapan Restorative Justice Terhadap Anak Sebagai Pelaku Tindak Pidana Asusila Dalam Perspektif Undang - Undang Nomor 17 Tahun 2016 Tentang Perubahan Kedua Atas Undang -Undang Nomor 23 Tahun 2002 Tentang Perlindungan Anak (Analisa Putusan No. 49/Pid.Sus-Anak/2019/PN. Tng). Rechtsregel Jurnal Ilmu Hukum, Volume 3 Nomor 1. hlm. 149.
} 
berbeda-beda pada setiap peraturan perundang-undangan yang terkait. Hal ini tentu akan membuat para penegak hukum memberikan putusan tidak relevan karena hanya berdasarkan kemiripan unsur-unsur perbuatan dari kasus-kasus anak yang berhadapan dengan hukum sebelumnya.

c) Kurangnya rasa saling mendukung dan kerja sama diantara para lembaga yang terkait. Tentu permasalaha ini akan menjadi penghambat dalam proses penegakan suatu ketentuan hukum. Banyak masyarakat yang masih menganggap bahwa diversi sama dengan mediasi, hal ini membuat banyak masyarakat yang menganggap bahwa diversi tidak memiliki kekuatan hukum yang tetap

Sebagai seorang aparat penegak hukum yang berwenang melakukan diversi, terdapat halhal yang dianggap menjadi faktor hambatan serta kendala bagi Penuntut Umum dalam penyelesaian perkara pidana anak yang berhadapan dengan hukum dalam menerapkan upaya diversi diantaranya adalah sebagai berikut ${ }^{31}$ :

1) Faktor susahnya menghadirkan para pihak, pelaku, korban, para orang tua pelaku dan korban, BAPAS, dan perwakilan masyarakat lingkungan korban dan pelaku

2) Faktor tidak terdapatnya kesepakatan diantara para pihak yakni orang tua korban dan pelaku, hal ini dikarenakan mereka terlalu mementingkan kepentingan anaknya masing-masing, seperti keluarga pelaku yang tidak menginginkan apabila anaknya dikenai hukuman, sedangkan keluarga korban memiliki perasaan ingin melakukan balas dendam terhadap pelaku dan merasa tidak puas apabila pelaku tidak dihukum. Apabila kondisi seperti ini terjadi maka akan membuat pelaksanaan diversi menjadi terhambat dan dapat menyebabkan tidak tercapainya kesepakatan diversi.

3) Faktor kurangnya pemahaman masyarakat tentang Diversi. Kurangnya pemahaman ini tentu akan membuat para pihak enggan melakukan upaya diversi.

\footnotetext{
${ }^{31}$ Mareta, Josefhin. (2018). Penerapan Restorative Justice Melalui Pemenuhan Restitusi Pada Korban Tindak Pidana Anak. Jurnal Legislasi Indonesia, Volume $15 \quad$ Nomor $4 . \quad$ hlm. 59. doi: http://dx.doi.org/10.30641/ham.2020.11.445-466
} 
4) Faktor kurangnya sarana dan prasarana yang masih belum memadai. Kurangnya sarana penunjang berupa ruangan khusus untuk pelaksanaan diversi pada tingkat penuntut umum untuk mempertemukan pihak-pihak yang terkait dalam pelaksanaan diversi tersebut. Mengenai kewajiban menyediakan ruang khusus dalam pelaksanaan diversi ini sudah tercantum pada Surat Keputusan Bersama MA RI, Jaksa Agung RI, dan Kemenkumham.

5) Faktor budaya hukum yang merupakan faktor kebiasaan. Kebiasaan masyarakat yang menganggap sistem penegakan hukum buruk dan tidak dapat berkembang akan menjadikan pelaksanaan penerapan diversi juga akan terkendala dan akan semakin terabaikan oleh masyarakat.

\section{PENUTUP}

\section{KESIMPULAN}

Penerapan diversi ini memberikan kesempatan kepada pembimbing kemasyarakatan, pelaku, korban, dan para orang tua pelaku dan korban, pendamping, penasehat hukum, perwakilan masyarakat, untuk menyampaikan pendapat, tanggapan, dan saran dalam proses berlangsungnya proses diversi tersebut. Jaksa Penuntut Umum dalam proses pengambilan keputusan berlandasakan pada kebaikan pelaku dan korban. Dalam perkara ini Jaksa Penuntut Umum Kejaksaan Negeri Jakarta Barat menerapkan diversi pada proses peradilan pidana anak dengan melakukan pendekatan kepada pelaku, korban, dan para orang tua pelaku dan korban, Balai Pemasyarakatan, serta masyarakat sekitar pelaku dan korban. Proses diversi yang dilakukan oleh Jaksa Penuntut Umum telah tercapai kesepakatan dengan pelaku dan orang tua pelaku untuk meminta kemudian meminta maaf kepada korban agar tindak pidana tersebut tidak dilakukan proses peradilan pidana. Kemudian untuk mendapatkan kekuatan hukum bahwa diversi yang dilakukan telah tercapai kesepakatan diantara para pihak, maka berita acara upaya diversi dan hasil penelitian Badan Pemasyarakatan akan dialihkan ke PN Jakarta Barat untuk selanjutnya dilakukan penetapan oleh Ketua PN Jakarta Barat. 
Sebagai seorang aparat penegak hukum yang berwenang melakukan diversi, terdapat halhal yang dianggap menjadi faktor hambatan serta kendala bagi Penuntut Umum dalam penyelesaian perkara pidana anak yang berhadapan dengan hukum dalam menerapkan upaya diversi diantaranya adalah sebagai berikut : Faktor susahnya menghadirkan para pihak, pelaku, korban dan para orang tua pelaku dan korban, BAPAS, dan perwakilan masyarakat lingkungan korban dan pelaku, Faktor tidak terdapatnya kesepakatan diantara para pihak yakni orang tua pelaku dan orang tua korban, hal ini dikarenakan mereka terlalu mementingkan kepentingan anaknya masing-masing, Faktor kuranngnya pemahaman masyarakat tentang Diversi, Faktor Kurangnya sarana penunjang berupa ruangan khusus untuk pelaksanaan diversi pada tingkat penuntut umum untuk mempertemukan pihak-pihak yang terkait dalam pelaksanaan diversi tersebut. Faktor budaya hukum yang merupakan faktor kebiasaan. Kebiasaan masyarakat yang menganggap sistem penegakan hukum buruk dan tidak dapat berkembang akan menjadikan pelaksanaan penerapan diversi juga akan terkendala dan akan semakin terabaikan oleh masyarakat.

\section{DAFTAR PUSTAKA}

\section{Penetapan Pengadilan dan Peraturan Perundang-Undangan:}

Penetapan Pengadilan Negeri Jakarta Barat Nomor 39/Pen.Diversi/Pid.SusAnak/2019/PN.Jkt.Brt

Undang-Undang No 11 Tahun 2012 tentang Sistem Peradilan Pidana Anak; Lembaran Negara Republik Indonesia Tahun 2012 Nomor 153; Tambahan Lembaran Negara Republik Indonesia Nomor 5332

\section{Buku:}

Hatta. (2016). Kapita Selekta Pembaharuan Hukum Pidana dan Sistem Pemidanaan. Yogayakarta: Liberti.

Husin, Kadri, Budi Rizki. (2016). Sistem Peradilan Pidana di Indonesia. Jakarta: Sinar Grafika. Marzuki, Peter Mahmud. (2016). Penelitian Hukum (Suatu Pengantar). Jakarta: Kencana Prenada Media.

Moleong, Lexy J. (2017). Metodelogi Penelitian Kualitatif. Bandung: PT Remaja Rosda Karya. Mulyadi, Lilik. (2016). Mediasi Penal Dalam Sistem Peradilan Pidana Indonesia. Bandung: PT Alumni. 
Paksi, T. F. (2016). Merefleksi Pendekatan Sosio- Legal Dalam Penelitian Hukum" dalam Penelitian Hukum Interdisipliner. Yogyakarta: Thafa Media.

Waluyo, Bambang. (2016). Desain Fungsi Kejaksaan Pada Restorative Justice. Jakarta: Rajawali Pers.

Widodo. (2017). Perspektif Hukum Pidana dan Kebijakan Pemidanaan: Diversi dan Keadilan Restoratif, Terorisme, Cybercrime, Pidana Mati, dan Peradilan Sesat. Yogyakarta: Aswaja Pressindo.

Wiyono, R. (2016). Sistem Peradilan Pidana Anak Di Indonesia. Jakarta: Sinar Grafika.

\section{Karya Ilmiah:}

Aidil., M. (2020). Penerapan Restorative Justice Terhadap Anak Sebagai Pelaku Tindak Pidana Asusila Dalam Perspektif Undang - Undang Nomor 17 Tahun 2016 Tentang Perubahan Kedua Atas Undang -Undang Nomor 23 Tahun 2002 Tentang Perlindungan Anak (Analisa Putusan No. 49/Pid.Sus-Anak/2019/PN. Tng). Rechtsregel Jurnal Ilmu Hukum, Volume 3 Nomor 1.

Andriyanti, Eka Fitri. (2020). Urgensitas Implementasi Restorative Justice Dalam Hukum Pidana Indonesia. Jurnal Education and development Institut Pendidikan Tapanuli Selatan, Volume 8 Nomor 4. doi: https://doi.org/10.52103/jlg.v2i1.287

Ariani, Ni Made Ita, Ni Putu Rai Yuliartini, Dewa Gede Sudika Mangku. (2019). Implementasi Undang-Undang Nomor 11 Tahun 2012 Tentang Sistem Peradilan Pidana Anak Terhadap Curanmor Yang Dilakukan Oleh Anak Di Kabupaten Buleleng (Studi Kasus Perkara Nomor: B/346/2016/RESKRIM). e-Journal Komunitas Yustisia Universitas Pendidikan Ganesha Jurusan Ilmu Hukum, Volume 2 Nomor 2. doi: http://dx.doi.org/10.23887/jatayu.v2i2.28776

Azizah, Hikmatul, Abd Wahid, Arfan Kaimuddin. (2021). Implementasi Penyelesaian Perkara Melalui Diversi Berdasarkan UU No.11 Tahun 2012 Tentang Sistem Peradilan Pidana Anak (Studi Kasus di Kejaksaan Negeri Kota Malang), Jurnal Dinamika, Volume 27 Nomor 3.

Hasbi Hasan. (2013). Penerapan Keadilan Restoratif Dalam Sistem Peradilan Pidana Anak Di Indonesia. Jurnal Hukum dan Peradilan. Volume 2 Nomor 2. doi: http://dx.doi.org/10.25216/jhp.2.2.2013.247-262

Isnatul Rahmi, Rizanizarli. (2020). Penerapan Restorative Justice Dalam Penyelesaian Tindak Pidana Pencurian Oleh Anak Dalam Perspektive Adat Aceh (Suatu Penelitian di Wilayah Kota Sabang). Jurnal Syiah Kuala Law Journal, Volume 4 Nomor 1. doi: https://doi.org/10.24815/sklj.v4i1.16876

Jonlar Purba. (2017). Penegakan Hukum Terhadap Tindak Pidana Bermotif Ringan Dengan Restorative Justice, Jakarta: Jala Permata Aksara. doi: http://dx.doi.org/10.26532/ijlr.v3i1.4366

Karim. (2016). Tanggung Jawab Pelaku Pidana Pelanggaran Dalam Perspektif Restorative Justice. Jurnal Ilmu Hukum, Universitas Airlangga, Volume 31 Nomor 3. doi: https://doi.org/10.21107/ri.v12i2.3244 
Marlina, Renhard Harve., Muhammad Ekaputra, Edy Ikhsan. (2016). Penerapan Diversi Pada Tingkat Penuntut Umum Terhadap Anak Sebagai Pelaku Tindak Pidana Menurut UU Nomor 11 Tahun 2012 (Studi Kasus Di Cabang Kejaksaan Negeri Padangsidimpuan Di Sibuhuan). USU Law Journal, Volume 4 Nomor 3.

Mahendra, Alfian dan Beniharmoni Harefa. (2020). Perlindungan Hukum Terhadap Identitas Anak Sebagai Pelaku Tindak Pidana Dalam Proses Peradilan Pidana. Jurnal Kertha Semaya, Volume 8 Nomor 10. doi: https://doi.org/10.24843/KS.2020.v08.i10.p13

Mareta, Josefhin. (2018). Penerapan Restorative Justice Melalui Pemenuhan Restitusi Pada Korban Tindak Pidana Anak. Jurnal Legislasi Indonesia, Volume 15 Nomor 4. doi: http://dx.doi.org/10.30641/ham.2020.11.445-466

Mita Dwijayanti. (2017). Diversi Terhadap Recidive Anak. Jurnal Rechtidee, Volume 12 Nomor 2. doi: https://doi.org/10.21107/ri.v12i2.3244

Kirom, Mizanul., Pujiyono, Endah Sri. (2016). Implementasi Diversi Dalam Penyelesaian Kasus Anak Yang Berkonflik Dengan Hukum Berdasarkan Undang-Undang Nomor 11 Tahun 2012 Tentang Sistem Peradilan Pidana Anak. Diponegoro Law Jurnal, Volume 5 Nomor 3.

Pradityo, Randy. (2016). Garis Lurus Diversi Sebagai Pendekatan Non-Penal. Jurnal RechtsVinding Online. doi:10.25216/JHP.5.3.2016.319-330.

(2016). Restorative Justice Dalam Sistem Peradilan Pidana Anak Restorative Justice In Juvenile Justice System. Jurnal Hukum dan Peradilan, Volume 5 Nomor 3. doi: http://dx.doi.org/10.25216/jhp.5.3.2016.319-330

Setiawan, Dian Alan. (2017). Efektivitas Penerapan Diversi Terhadap Penanganan Anak Yang Berhadapan Dengan Hukum Dalam Peradilan Pidana Anak Sesuai Undang-Undang Republik Indonesia Nomor 11 Tahun 2012 Tentang Sistem Peradilan Pidana Anak. DiH Jurnal Ilmu Hukum, Volume 13 Nomor 26. Fakultas Hukum Universitas 17 Agustus Surabaya. doi: https://doi.org/10.30996/dih.v0i0.1585

Sitanggang, Betania Fransiska, Irma Cahyaningtyas. (2020). Penanganan Perkara Anak Dalam Perspektif Jaksa Penuntut Umum. Jurnal Pembangunan Hukum Indonesia Program Studi Magister Ilmu Hukum, Volume 2 Nomor 1. 